\title{
Body Politics in the COVID-19 Era from a Feminist Lens
}

\author{
Emilia Reyes ${ }^{1}$
}

Published online: 13 November 2020

(c) Society for International Development 2020

\begin{abstract}
The premises of the feminist economist tradition from the Global South center their analysis in the wellbeing of people and the planet, under the human rights framework, gender equality and environmental integrity, as cross-cutting principles. The pandemic brought to the surface what the feminist movement has been saying all along, namely that the wellbeing of persons, and the planet they live in, depends on a complex web of elements beyond a limited notion of bodily health. The current capitalistic system has always kindled a tension between life and profits, a game that has undermined human rights of all persons by prioritizing the circulation of merchandises, goods and capitals. That struggle is more acutely felt now with the confinement measures imposed all around the world, and the ensuing impossibility for millions of people in precarious circumstances of respecting the lockdown measures. Women are even more carrying the burden of subsidizing entire economies. The feminist movement is now looking at solutions of solidarity at the crossroad between and within social movements, public policy, local and community resistance, while refusing to go back to a world where women may have to subsidize even more entire economies under recession.
\end{abstract}

Keywords Body politics · Feminist macro-economy $\cdot$ Unpaid domestic and care work $\cdot$ Social disasters $\cdot$ Feminist activism · Global economic solutions

\section{Reading the COVID-19 Pandemic Through the Gender Lenses}

The analytical category of gender implies a social construction around the sexual anatomical difference. It highlights the interrelation of two relevant dimensions: the human body and the way humans experience their bodily dimension. Bodies and their processes cannot be detached from their historical and social contexts. Through this analytical category we are able to see the multiple dimensions of a crisis such as the current one. At a time when humanity faces unprecedented risks in relation to its surroundings, and to events that challenge the health of the human body and the wellbeing of human life across the world, we cannot but emphasize the social construction of our realities. A threat to our individual health is also a threat to our collective wellbeing. The reflection regarding our social dynamics demand far more than mere health measures.

Emilia Reyes

emilia@equidad.org.mx

1 Equidad de Género: Ciudadanía, Trabajo y Familia, Mexico City, Mexico
Individual and bodily health is to be conceived in its social dimension. We speak of public health when life conditions of entire groups are so intertwined that there is no way to think of health measures based on individuals alone. Such measures need to be shaped in accordance to the dynamics of the collective body. In fact, the overarching impact of COVID-19 on every aspect of our lives compel us to even look beyond the single concept of public health.

In The Lancet, Richard Horton suggests that COVID-19 is not a pandemic but a syndemic, reflecting the effect of 'health and social interactions that are important for prognosis, treatment, and health policy' (Horton 2020). The interaction has an effect on each of the components: 'Syndemics are characterized by biological and social interactions between conditions and states, interactions that increase a person's susceptibility to harm or worsen their health outcomes'. We have seen worldwide multiple inequalities strongly linked to the comorbidities associated with the harshest impact of SARS-CoV-2 among the groups at greater risk of complications and death. The populations suffering from the most extreme inequalities are also those having the least access to the preventive and mitigation measures, so that the negative social interactions go both ways. The result is that extreme 
inequalities are further exacerbated once the virus hits the most disenfranchised communities. Being confronted with a syndemic means that humankind will not be able to address the real challenges posed by the virus unless and until the structural causes of inequalities are addressed. From such viewpoint, health measures alone will not be enough. Nor will be the short-term economic response aimed to mitigate the consequences of productive activity's temporary suspension.

At least two decades ago, the alternative Latin American tradition of Disaster Risk Management had warned about the structural origins of socio-natural phenomena leading to disaster risk. The deep roots of such events were to be mainly found in the failure of the predatory and extractive economic system, in the imbalance on power relations and in the lack of medium/long-term policies to address both drivers. Disasters are the result of multi-causal events, and the materialization of un-managed risks. In the stages of handling and recovering from a disaster, both ex ante and $e x$ post, the only possible approach to look towards the future is tackling the root causes of risk related to the economic system while promoting a more democratic weaving of the social bond. Socio-natural disasters, such as pandemics, have been appropriately analyzed under these lenses (Castro and Reyes 2006). Experts from this tradition even refused to refer to 'natural' disasters, preferring to call them 'social' disasters, thereby placing the emphasis on those who suffer the impacts rather than on the threat. The reason of this semantic shift was practical: when a disaster is 'natural', the risk is shifting away from collective responsibility. Recognizing the 'social' dimension, instead, implies that the focus is centered on the societal and governmental responsibility for risk prevention and effective action in the face of an emergency. In view of the needed re-construction with long term objectives to mitigate/eliminate the risk of future recurrence of the same disaster, human rights and gender equality should be prioritized by governments at all moments.

Throughout decades, feminist economists of the Global South have advocated for the need of a paradigm shift of the economic model, placing the wellbeing of people and the planet at the centre rather than prioritizing economic and financial flows alongside the exchange of goods. The encompassing feminist economic model embraces the human rights framework, ensures gender equality and environmental integrity while promoting democratic processes at the different levels of governance.

However, life has been seriously threatened by this capitalistic and neoliberal system. In this article, life should be understood as we know it, not only human life, but the healthy life of the Planet, the survival of biodiversity and the integrity of ecosystems. No time has ever shown the damage of our anthropocentric view to the extent defining this era. Also, it is crucial to single out its negative pervasive effects produced on lives in the Global South, on the daily existence of those who have most suffered the global neoliberal white supremacist division of labour. The devastating results are just as well evident, like a fractal, ${ }^{1}$ in racialized communities and in communities whose identities were anthropogenically conceived in a notion of alterity by this system for the very purpose of their exclusion (LGBTI, disability, migrants, and others).

COVID-19 is powerfully revealing the way in which the human body is subjected to body politics: In the name of 'saving lives' we have witnessed enormous abuses to social life. Under the cover of their responses to the pandemic, many governments have turned to undemocratic processes that have further harshened the balance of power, while endangering the safety of environmentalists and human rights defenders. ${ }^{2}$ In many countries there are new open threats to democracy and civil rights, in the form of attacks against activists promoting social and racial justice-like the violence faced by Black Lives Matter and anti-fascist activists in the USA. Feminist activists calling for sexual and reproductive health and rights, or protesting against the increase of gender-based violence, are the targets of violence. In reaction to the many democratic violations around the world, feminist have demanded that lockdowns and confinement measures be carried out by upholding a democratic framework. ${ }^{3}$

As for the lockdowns themselves, alarming trends around the world signal a gross regression in the exercise of women's human rights. While all of these challenges are dramatically exacerbated in contexts of conflict, body politics are also fully at play when public discourses emphasize the priority of ensuring the safety and health of people, especially

\footnotetext{
${ }^{1}$ Fractals are complex geometric structures with patterns of infinite and irregular iteration in self-similarity. Since 1975, fractal geometry is crucial notion for science. Fractals have also been applied to social science in the past decade to reflect both structural and multiple dimensions of human life, as well as the singularity of every event. https://www.britannica.com/science/fractal Accessed 26 October; For more on the use of fractals in social science and philosophy Grössing (1993).

${ }^{2}$ For an account on the impact of COVID 19 lockdowns on environmentalists and human rights defenders, https://www.business-human rights.org/en/big-issues/covid-19-coronavirus-outbreak/covid-19human-rights-defenders-and-civic-freedoms/; https://www.frontlined efenders.org/en/campaign/covid-19-attacks-hrds-time-pandemic Last seen on October Accessed 15 October.

${ }^{3}$ In particular, feminist activists have called for 'zero tolerance for restrictions and regulations not proportionate and effective in dealing with the pandemic, that shrink human and democratic rights and personal liberties, establish or consolidate authoritarian regimes, and that are enforced militaristically'. Feminist Response, Principles: COVID-19 responses must be based on and strengthen democratic values: https://www.feministcovidresponse.com/principles/ Accessed 15 October 2020
} 
when this is done by short-cutting governments' mandate to ensure sexual and reproductive rights, i.e. by slow or lacking response to address the disruption of essential sexual and reproductive health commodities, including menstrual health items or contraceptives. It also occurs when conservative forces push for evidently regressive pathways in global resolutions on COVID-19 negotiations, as was the case of the UN's Omnibus resolution on COVID-19. ${ }^{4}$ Meanwhile, gender-based violence in domestic and public settings has increased at an alarming rate, a problem documented across the world.

\section{Body Politics and the Implications for Women}

Well before COVID-19, it was known that because of the sexual division of labour women were subsidizing the global economy by undertaking most of the unpaid domestic and care work (existing estimates point out to women producing two-thirds of the value that circulates in the world). ${ }^{6}$ In the recurrent scenario of austerity measures and reduction of social spending, women become shock absorbers; economists even call this an effect of the 'great elasticity' of women's time in relation to work, meaning that women

\footnotetext{
${ }^{4}$ The omnibus resolution titled, Comprehensive and coordinated response to the coronavirus disease (COVID-19) pandemic, adopted on 11 September 2020, faced harsh times before it being adopted. The Operative paragraph 7 on sexual and reproductive health and rights underwent a specific vote, due to the conservative push against this agenda. https://undocs.org/A/74/L.92 Accessed 17 October 2020.

5 Joint statement by the Special Rapporteur and the EDVAW Platform of women's rights mechanisms on Covid-19 and the increase in violence and discrimination against women, Geneva, 14 July 2020, https://www.ohchr.org/EN/NewsEvents/Pages/DisplayNews.aspx? NewsID?=?26083amphersandLangID?=?E. Accessed 15 October 2020

${ }^{6}$ Figures of the value generated by unpaid domestic and care work around the world still depend on studies of costing paired along data obtained by time surveys and satellite accounts. In general, women are estimated to perform around $70 \%$ of all of the unpaid domestic and care work globally (yet, multidimensional discrimination also plays a great role here, i.e. indigenous and rural women undertaking more hours and tasks than urban women). Studies based on costing in terms of GDP - the assumption being that this type of work would receive a minimum wage-show that women labour would amount to around one-fifth of the entire GDP in a country. But estimates of direct remuneration for different activities paid in the market show that the value generated could amount to more than the money currently circulating in the world. In other words, the estimation includes monetized and non-monetized value. This would mean there is not enough money to pay for the value generated by unpaid domestic and care work. The estimation greatly depends on the methodology. For more on the macro-economic dimension of care, Antonopoulos, Rania, 'The unpaid care work - paid work connection', ILO, 2009, https://www.ilo.org/wcmsp5/groups/public/---dgreports/---integratio n/documents/publication/wcms_119142.pdf Accessed 26 October
} 2020 undertake the tasks externalized by the state, such as caring of sick people, the elderly and others (Pearson and Sweetman 2011). Now, the lockdowns have highlighted that the sexual division of labour remains as present and structural as ever, with women having to face the social expectations of them undertaking the domestic and care work for the rest of their family and community members. In this sense, when we say that body politics have been at play during the COVID-19 crisis, we mean that states have naturalized the sexual division of labour, through provision of different destinies to women and men.

The widespread use of 'women's empowerment' as a so-called solution reflects precisely the resistance to promote the structural transformation that would be required to ensure women's human rights and eradicate the sexual division of labour. The COVID-19 pandemic has reversed women's human rights decades back, precisely because of the implicit expectation of women undertaking all the burden of paid and unpaid domestic and care work, while having to endure very precarious and downgraded work conditions in their other formal and informal jobs. Women remain at the bottom of public concern, despite the enormous negative impact of multiple discrimination, when it is articulated to conditions related to race, age, geographic condition, and others. $^{7}$

Despite the social gains women have made throughout modern history, in their painstaking and incessant transiting towards the public sphere, the many COVID-19 related lockdowns around the world have proven that governments' role in ensuring the sexual division of labour proves to be 'efficient' for the circulation of capital and goods. Despite for calls to guarantee women's human rights, governments and International Financial Institutions (IFIs) have not only been blind to this structural dimension, but they actually keep promoting austerity measures as part of the 'recovery' from the recession caused by COVID-19. It has been widely proven that women are more disproportionately impacted than men by austerity measures and fiscal consolidation policies, while these also exacerbate discrimination and inequalities. $^{8}$

\footnotetext{
7 'Women's empowerment', in this sense, has operated as a very damaging and regressive term to minimize the systemic dimension of inequalities by relying on the individual or community level, rather than on the imbalance of power and structures at stake playing against women's human rights. The responsibility to guarantee human rights falls in the shoulders of State as duty bearers. Under no circumstance women should be expected to solve their condition of structural inequalities on their own.

8 'Impact of economic reforms and austerity measures on women's human rights', Report of the Independent Expert on the effects of foreign debt and other related international financial obligations of States on the full enjoyment of all human rights, particularly economic, social and cultural rights, Juan Pablo Bohoslavsky, A/73/179,
} 
From the macro-economic point of view regarding gender, it is clear then that the decision to promote austerity measures relies on exploiting women and discriminated groups of population instead of addressing the structural elements that are really at the root cause of the multiple crises humanity is facing nowadays. UNCTAD's Trade and Development Report $2020^{9}$ warns of a 'lost decade' if countries adopt austerity, recommending instead 'tackling a series of pre-existing conditions that were threatening the health of the global economy even before the pandemic hit' such as '(...) hyper-inequality, unsustainable levels of debt, weak investment, wage stagnation in the developed world and insufficient formal sector jobs in the developing world'. ${ }^{10}$ We will come back to these issues later on in this article.

Globally, the United Nations Secretary General, António Guterres, said women are also seeing 'a threat to their incomes: about 60 percent of women around the world work in the informal economy, hence at greater risk of falling into poverty'. ${ }^{11}$ In parallel, for those women who have not been able to remain in confinement, either because they are at the forefront of the response $\mathrm{e}^{12}$ or because of their situation of poverty or geographic conditions, lack of access to basic services such as water and sanitation or housing constitute structural barriers to preserving their wellbeing. There has been a blatant Governments' omission in ensuring their basic needs and rights.

\section{Antigone versus Creon in times of COVID}

The current COVID-19 crisis is also confronting us with new challenges; these may remain invisible to the wider perception, yet they are very real to those whose lives have

\footnotetext{
Footnote 8 (continued)

18 July 2018. https://www.undocs.org/A/73/179 Accessed 26 October 2020

9 Trade and Development Report 2020. From Global Pandemic to Prosperity for All: Avoiding Another Lost Decade, UNCTAD, 2020. https://unctad.org/system/files/official-document/tdr2020_en.pdf Accessed 17 October 2020

10 COVID-19: UNCTAD warns of 'lost decade' if countries adopt austerity, UNCTAD, 21 September 2020. https://unctad.org/news/ covid-19-unctad-warns-lost-decade-if-countries-adopt-austerity Accessed 17 October 2020

11 COVID-19 worsening gender inequality, more women have lost jobs - UN, Daily Post, 10 April 2020. https://dailypost. ng/2020/04/10/covid-19-worsening-gender-inequality-more-women -have-lost-jobs-un/Accessed 15 October 2020.

12 There are many articles documenting by countries and regions the way women have been at the forefront of the response. This relates to the way in which the sexual division of labor assigns for women roles pertaining to nursing, cleaning, caring for those most in need in communities, and others.
}

been touched by the SARS-CoV-2 virus. As Corina Rodríguez noticed, ${ }^{13}$ so far this unprecedented event has been a major health crisis with human bodies being hidden to our eyes, as if those battling the disease should be erased out of our view. On the one hand, people who have fallen ill with COVID-19 are being imposed isolation. ${ }^{14}$ On the other, if they are well enough (meaning: 'not with risk of death'), they should go through the illness without resourcing to the public health sector.

The Mexican government, for instance, has insisted that only extremely sick people (with troubled breathing, mental confusion, concurrent high fever) should go to the hospital. Exception made of people with comorbidities, elderly persons or pregnant women, for anyone else feeling symptomatic, the regular practice during the pandemic has been to remain at home in isolation, taking medications that may treat the main symptoms, in order to avoid hospital saturation. Due to a fatal mix of factors, COVID-19 related deaths rose fast and exponentially in Mexico. The high level of comorbidities in the Mexican population-linked to extreme poverty but also to the massive consumption of highly processed food and beverages - is at the core of the high morbidity, coupled with the fact that $60 \%$ of the population works in informal sector. Like in many other countries, decades of depletion of the country's health sector have weakened state capacity to handle the quick progression of the disease. $^{15}$

The prescription of isolation and individualizing the impact of the illness without bearing in mind the social bond has also many implications: in many countries, suffering from COVID-19 is equivalent to being subjected to stigma and discrimination. For those convalescing at home the

\footnotetext{
${ }^{13}$ Corina Rodríguez, in the Webinar, Economías Pandémicas y cuidados: Pensando alternativas transformadoras desde la emergencia, organized by Confluencia Feminista rumbo al Foro Social Mundial de Economías Transformadoras, 21 May 2020. https://www.facebook. $\mathrm{com} / \mathrm{watch} / \mathrm{?}=264847981562340$. Accessed 17 October 2020.

${ }^{14}$ People sick with COVID-19 are told to remain in isolation, away from others, even in their own home, to avoid contagion. People who possibly were in contact with someone sick with COVID-19 are told to quarantine, away from others, for 14 days. https://www.cdc.gov/ coronavirus/2019-ncov/downloads/COVID-19-Quarantine-vs-Isola tion.pdf Accessed October 262020.

15 By the time this article was written, Mexico is almost reaching 90,000 deaths. Mexico is an interesting country from the point of view of disaster risk management: due to a specific Civil Protection strategy devised since the 1985 earthquake, Mexico consolidated the deployment of mobile hospitals with the help of the armed forces. Even at the peak of contagion and deaths, Mexican hospitals were not saturated to the extent of other countries with the same figures -or even less- as Mexico. Many things can be said on the matter from the point of view of 'securitizing' health, and the impacts of a military deployed in a territory affected by a pandemic, including specific problems for women, such as an increase of sexual harassment and unwanted pregnancies (Castro and Reyes 2006).
} 
range of social resentment can take a variety of forms, from accusations of exposing their neighborhoods or villages to the risk of the virus, to violent attacks expelling them from their communities. ${ }^{16}$

Hospitals and clinics are micro-cosmos of their own, but not devoid of the conflictive perceptions on the pandemic in the outside world. The phenomena of stigma have expanded to healthcare providers: a wide literature of country reports have documented discrimination against healthcare providers, adding another layer to the risk they face in combating COVID-19. ${ }^{17}$ As for patients hospitalized, they are rigorously isolated from their families. Thousands of people have died alone, often after days or even weeks without real human care. Their beloved ones in solitude also, unable to cope with the distancing first and then the departure.

The early months of the crisis brought about a tragic conversation about the 'value of life', often because underfunded health sectors were at their full capacity. The medical triage, supposedly a pragmatic solution to weigh-in in decisions when faced with scarcity of medical infrastructures, ended up reflecting an extremely discriminatory society. Those deemed least likely to survive-people with disability or comorbidities-raise compelling questions about our unequal societies, or ageist and essentialist conceptions. Through the prism of human rights, these protocols do not stand a more complex revision. For the months and years ahead, when it comes to public policies, medical triage cannot replace proper planning and budgeting, or differentiated protocols addressing the diverse groups of the population's needs.

In the logic of body politics, the extent of what is to be prioritized and what not, is extreme. Corina Rodríguez points out the strange phenomenon of a pandemic with an extremely high number of deaths but no dead bodies. States have disposed of them following strict health emergency guidelines, but also depriving mourners from the variety of processes that our human societies have devised to symbolically cope with death. So far, there has not been a collective and global call from governments to address the symbolic dimension of the extent of loss humanity is facing right now. Rodríguez points out that in history's past pandemics (in the last one called 'the Spanish flu' in 1918, but even more in previous centuries), people dying would collapse on the streets and be piled up due to lack of proper infrastructures, corpses would then be seen out in the open. Such

\footnotetext{
16 COVID-19-related discrimination and stigma: a global phenomenon? UNESCO, 25 May 2020. https://en.unesco.org/news/covid-19related-discrimination-and-stigma-global-phenomenon Accessed 15 October 2020

17 Attacks on health care in the context of COVID-19, WHO, 30 July 2020, https://www.who.int/news-room/feature-stories/detail/attackson-health-care-in-the-context-of-covid-19 Accessed 15 October 2020.
}

experiences brought their own dimensions of horror but also the threatening reality of the pandemic. With tragic exceptions, the current massive disposal of corpses outside the public view can be one of the complex reasons why many people are still in disbelief and denial of the pandemic. ${ }^{18}$ From a different angle, the management of anonymous dead bodies, deprived of their proper symbolic recognition, brings about an immense void: a deep wound, not quite traceable in any specific part of our collective body. And yet, the tragedy of the exceptionality stares back at us. Ecuador went through weeks of anguishing scenes of corpses lying on the streets in Guayaquil, with funerary services at capacity, and the fear of not having the proper health protocols to dispose of them. ${ }^{19}$ New York City faced a scandal for some days about the accumulation of decomposed corpses piled up in trucks, struggling with delivering proper burials. ${ }^{20}$ Authorities of Manaus in Brazil rushed to dig mass graves. ${ }^{21} \mathrm{~A}$ disaster risk management strategy with a gender perspective recognizes the need for a dignified disposal of the bodies, notwithstanding the stressing conditions the emergency brings about (Castro and Reyes 2006).

In these unprecedented times, what are the implications of socially distanced public ceremonies, of funerals or symbolic acts of collective mourning being treated as exceptions rather than the rule? Corina Rodríguez explains how feminists need to focus on human death the same way that we have focused on the wellbeing of life. Governments feel the urge and the comfort in communicating numbers: the 'figures' of the infected, of those who have recovered, of the dead. Numbers that overpass the million death toll by now. Yet, the wounds include the psychological trauma, the effects of governments' omissions in dealing with collective grief.

Mexico, a country with a deep attachment to death rituals and ceremonies to honor its dead and ancestors, is already

\footnotetext{
${ }^{18}$ Denial is a broader problem, extending to science denial and the distance between the governmental discourse and the perceptions of people in their immediate realities. Either inflamed by dictatorial and populistic governments, or as a reaction to the multiple impacts of the current crises, there is certainly a gap between what is the mandate of the State and what many groups of population are contending as their space in the context of a social pact.

${ }^{19}$ Bodies lie in the streets of Guayaquil, Ecuador, emerging epicenter of the coronavirus in Latin America, The Washington Post, 3 April 2020. https://www.washingtonpost.com/world/the_americas/coron avirus-guayaquil-ecuador-bodies-corpses-streets/2020/04/03/79c78 6c8-7522-11ea-ad9b-254ec99993bc_story.html Accessed15 October 2020 .

20 'We ran out of space': Bodies Pile Up as NY Struggles to Bury its Dead, The New York Times, 30 April 2020. https://www.nytim es.com/2020/04/30/nyregion/coronavirus-nyc-funeral-home-morgu e-bodies.html Accessed 15 October 2020.

21 ''Utter disaster': Manaus fills mass graves as Covid-19 hits the Amazon', The Guardian, 30 April 2020.
} 
facing a backlash due to the government 's decision to cancel the festivities of the Day of the Death on November 1st and 2 nd, and not only because of the economic losses. ${ }^{22}$ Several cities and states in the Mexican Republic have cancelled the Day of the Death festivities, including Mixquic, one of the most traditional villages celebrating these ceremonies in the entire country -with an income loss brought about by the one million missing attendants, both from international and national tourism. ${ }^{23}$ The festivity is deeply embedded in traditional beliefs which date back to pre-Hispanic times: the celebration is considered a deep commitment with ancestors. With the cancelling of the festivities, the Mexican government is reminiscent of a modern Creon. It will not be enough to stop the ancient memorial of the dead by the people of Mexico, embodying an ethical Antigone paying respects to the spirit of the beloved ones in their death ritual, prioritizing the family bonding and duty above the normative logic of the polis. ${ }^{24}$

The interests played around within the State, and, even more, around the global players, define what is regulated and what is not, what is of relevance and what is not. Capital versus life. This struggle in the end defines not only the wellbeing but the quality of life for some people above others. The more we highlight the macro dimension of gender, the more we realize that gender is not only a national agenda, but a global one, related to all the macro challenges humanity is facing nowadays.

\section{A Feminist Approach to Global Solutions}

Feminist groups around the world have reacted not only to provide analysis of the current global challenges, but also to provide solutions. One of the first global collectives around COVID-19 was the group around the Feminist Response. ${ }^{25}$

\footnotetext{
${ }^{22}$ Se inconforman vecinos por el cierre de panteones en Muertos, La Jornada, 14 October 2020. https://www.jornada.com.mx/ultim as/capital/2020/10/14/se-inconforman-vecinos-por-el-cierre-depanteones-en-muertos-7761.html?fbclid?=?IwAR2aHCtcamRE_ n55QpRC6Y9aWtqRiOubMdrK3ZwNabgGFjZW1WC3qdCwR-A. Accessed 15 October 2020.

${ }^{23}$ Mixquic se queda sin festejo de Día de Muertos por primera vez en su historia, UNOTV.Com, 6 October 2020. https://www.unotv.com/ reportajes-especiales/dia-de-muertos-2020-cancelan-celebracion-enmixquic-por-covid/Accessed 15 October 2020.

24 Tending to the psychological needs of population during the response and after and emergency has proven to be crucial for posterior economic and societal recovery (Castro and Reyes 2006).

${ }^{25}$ The Feminist Response to COVID 19 includes '(...) organizations and activists, working across global movements centered on human rights, sustainable development, and economic and social justice we have come together in a moment of collective organizing to outline key principles for a just and resilient recovery from the ongoing global pandemic, as well as to track responses and uplift collective action of feminists around the world'. The group's face to the world is
}

It would be difficult to pay homage to the effervescent activity of feminists in their countless analyses, proposals and actions throughout the COVID-19 era, but the collective Feminist Response is trying to map the harvest of diverse feminists groups and is a good entry point to recognize their tireless work around the globe, despite the shrinking space for meaningful participation at all levels. Governmental processes and international negotiations have turned to videocalls, eroding most of the conditions that can ensure transparency, accountability and meaningful participation. Globally, women and feminist organizations have also seen their funding dangerously been reduced, despite the crucial role they undertake in their communities.

What is States' response in the face of citizens' challenges and movements' demands? Many high-sounding declarations have been made at national level, but hardly any measures have properly addressed the impact of global challenges on women, and the macro-economic routes to gender equality. What we have seen instead is the predominant trend to promote short-term solutions rather than systemic ones. In the multilateral field we hear calls for 'Building Back Better'. Which means reinforcing the same measures that led us to where we are. Some have said COVID-19 marks the end of an era, but it is the opposite: the trends indicate we are even deepening the problem and sending millions of people to extreme poverty. In the words of Barbara Adams: 'Yet again people around the world were witnesses to the enormous gap between the well- articulated diagnosis of where we are and what needs to be done not only in the face of COVID-19 but also of pre-existing inequalities, vulnerabilities and multi-dimensional violence'. ${ }^{26}$

The diagnosis links to an urgent call from the feminist movement in bringing back to the main scene the public sector. At the national level, to strengthen the policy space to promote much needed reforms in several fields: from expanding the room for domestic resource mobilization (i.e. by moratory of debt payments; promoting progressive

\footnotetext{
Footnote 25 (continued)

through the website https://www.feministcovidresponse.com/, around a series of principles to respond to COVID, sharing resources, feminist reactions and analysis, webinars and online video materials produced by feminist around the world, as well as a tracker to evaluate different COVID responses around the world. Accessed 17 October 2020.

${ }^{26}$ Adams continues: 'Could it be, she asked, that the UN has been 'captured' as the President of Equatorial Guinea lamented: 'We cannot accept [either] that after so many years, the Charter of the UN continues to preserve the primacy of the major powers who trample on the legitimate aspirations of the weak so that they can enjoy the advantages of the UN system.' 'Thalif Deen, UN Survives a World Turned Upside Down', IPS News Agency, 16 October 2020. http://www.ipsnews.net/2020/10/un-survives-world-turned-upside/ Accessed 17 October 2020
} 
taxation) to ensuring better spending through Gender Responsive Budgeting, devising differentiated policies to eradicate inequality gaps and redistribute wealth while ensuring wellbeing for people and the Planet; as well as permanent support for the population via universal social protection floors (the only measure which can really target the myriad of challenges people face in their daily life). However, at national level there is little capacity to fully undertake these recommendations. Major social budgetary cuts are now taking place in developing countries, in sectors already wounded by decades of austerity measures. Countries barely have the policy space to react in a proper manner. Those willing to do it are over-indebted, or facing the threat of the activation of Investor-State Dispute Settlements (ISDS) clauses when their responses to COVID-19 in defense of public goods clash with private interests. Such is the case of Peru, Guatemala, Bolivia and others. ${ }^{27}$

Just as evidently, in order to carry out those measures at the national level to the needed extent, a major structural reform of the international financial, trade and economic arenas is required at the global level. The Civil Society Group on Financing for Development and the Women's Working Group on Financing for Development (WWG on FfD) launched an open call for Global Economic Solutions Now! and are promoting a Campaign of Campaigns to raise awareness and rally support for global economic demands holding at the core a decolonial and feminist vision, promoting the wellbeing of people and the Planet while ensuring human rights and democratic global governance. ${ }^{28}$

This proposal is based on the following overarching principles:

- Human rights, gender equality, wellbeing, social-economic and environmental justice.

- Socio-economic transformation and a just, equitable transition for people and the planet.

- Democratization of global economic governance and inclusive participation at all levels.

The demands are:

(1) A New Global Economic Architecture that works for the People and Planet, under the auspices of the UN: an International Economic Reconstruction and Systemic Reform Summit.

\footnotetext{
${ }^{27}$ More ISDS cases launched against Latin American states amid the COVID-19 pandemic, AFTINET, 1 September 2020. http://aftin et.org.au/cms/node/1918 Accessed 17 October 2020.

28 Time for a UN Economic Reconstruction and Systemic Reform Summit. Towards a New Global Economic Architecture that works for the People and Planet, https://csoforffd.org/global-economic-solut ions-now/Accessed 17 October 2020.
}

(2) Debt cancellation, SDRs issuance and Sovereign Debt Workout Mechanism at the UN.

(3) Establishing a UN Tax Convention for redistributive justice, eliminating regressive taxation and illicit financial flows.

(4) Creation of a Global technology assessment mechanism at the UN.

(5) Fully Assess development impacts of current trade and investment framework.

(6) Assess systemic risks posed by unregulated or inadequately regulated financial sector instruments and actors.

(7) Review development outcomes of PPPs and 'private finance first' approach.

(8) Review of the ODA framework.

The efforts in building larger alliances between different movements in the social, economic and environmental justice fields are already starting to present common fronts in relation to each demand.

The WWG on $\mathrm{FfD}^{29}$ has been working throughout this time to raise awareness and promote an open space to make the connection between the macro demands of this campaign and the gender dimension in an intersecting manner, human rights and environmental integrity. ${ }^{30}$ The feminist movement is now looking at solutions at the intersection of solidarity between and within social movements, public policy, local and community resistance, as well as challenging the premise of building back better, refusing to go back to a world in which women are subsidizing even more entire economies going under recession. The element that distinguishes the COVID-19 era is that social movements, including the feminist movement, are awaking to the urgent need of collective action and alliances at all levels. There was always an understanding of the need for these alliances, and during major pivotal moments of past decades movements have come together to work jointly. Now the feminist analysis is also at the core of the solutions, and the feminist action is more needed than ever. The time to act with ambition is now, and the time to shatter structures could not be at the reach of

\footnotetext{
${ }^{29}$ An alliance of women's organizations and networks which advocates for the advancement of women's human rights and gender equality in the Financing for Development related UN processes.

${ }^{30}$ For the gender dimension of these macro-economic demands, Macro Solutions for Women, the People and the Planet, https://www. equidad.org.mx/Noticias/2020/09/29/macro-solutions-for-womenthe-people-and-the-planet-womens-working-group-on-financingfor-development-key-messages-and-inputs/Accessed 17 October 2020. For an in-depth conversation on these agendas, see the webinar series Macro Solutions for Women, the People and the Planet: https:// www.youtube.com/channel/UCPJHwi7LJNwpI66egmXPpAg?view_ as?=?subscriber. Accessed 17 October 2020 .
} 
our collective hands more closely than Now. It is up to us, the people, to make it happen.

\section{References}

Castro, Cecilia, and Emilia Reyes. 2006. Desastres 'naturales'y vulnerabilidad de las mujeres en México. Mexico: Inmujeres, UNDP, SEGOB, SNPC.

Grössing, Gerard. 1993. Atomism at the end of the twentieth century. Diogenes 163.
Horton, Richard. 2020. Offline: COVID-19 is not a pandemic. The Lancet 396(10255): 874, 26 September. https://www.thelancet. com/journals/lancet/article/PIIS0140-6736(20)32000-6/fulltext. Accessed 13 October 2020.

Pearson, Ruth, and Caroline Sweetman (eds.). 2011. Gender and the economic crisis. OXFAM and Practical Action Publishing.

Publisher's Note Springer Nature remains neutral with regard to jurisdictional claims in published maps and institutional affiliations. 